\title{
INTRODUCTION: "ALL THE EVIL OF THE TIMES"
}

On May 6, 1954, weary and disheartened after a grueling month-long hearing to assess his "loyalty" and, therefore, his eligibility for security clearance, Dr. J. Robert Oppenheimer left Washington, D.C., and returned home to Princeton, New Jersey. Although Oppenheimer had headed the program to build an atomic bomb during World War II, and had chaired the Atomic Energy Commission's (AEC) General Advisory Committee from 1947 to 1952, neither his past service nor his eminence had shielded him from suspicion or from the snooping that so often accompanied it. While his case was before the AEC's Personnel Security Board, his telephone had been tapped, his mail tracked, and his whereabouts noted by the Federal Bureau of Investigation (FBI). The surveillance, which had begun before the hearing started, remained in place even after it ended, which accounts for the report filed on May 7 describing his reaction to the ordeal. Oppenheimer was overheard to say that it would take many weeks for the board to reach a decision and for the AEC to render final judgment, "but he believes he will never be through with the situation. He does not believe the case will come to a quiet end as all the evil of the times is wrapped in this situation." 1

If we construe his phrase- "all the evil of the times"- to refer to the manifold ways in which, in the 1950s, a virulent strain of cold war anti-communism undermined ideals of decency, justice, and fair play, then Oppenheimer was surely right. Taken in combination, the various aspects of the case-Pres-

1. “Dr. J. Robert Oppenheimer: Summary for May 7, 1954." FBI Security File: J. Robert Oppenheimer (Scholarly Resources Microfilm), hereafter cited as FBI File. 
ident Dwight D. Eisenhower's initial decision to suspend his clearance, the tactical maneuvering that preceded the hearing, the manner in which the inquiry was conducted, the process by which ostensibly secret testimony was made public, and the justifications offered by the board and the AEC for voting to deny clearance-provide a classic illustration of what is meant by "McCarthyism."

Use of the term is appropriate even though Senator Joseph McCarthy played virtually no personal role in the outcome. In the spring of 1954, the junior senator from Wisconsin was preoccupied with a different set of hearings: the Senate's permanent Subcommittee on Investigations was investigating his allegations that the United States Army had been engaged in "promoting, covering up, and honorably discharging known Communists."2 The Army-McCarthy hearings began on April 22 and ended on June 17, thus coinciding almost exactly with the AEC deliberations in the Oppenheimer case. But where the Army-McCarthy contest took place in a gaudy atmosphere, replete with reporters, microphones, flash bulbs, and television cameras, the Oppenheimer hearing was conducted behind closed doors, with a civility that barely cloaked its contentiousness. Although newspapers printed the AEC's charges against Oppenheimer and his reply, and told their readers that an inquiry was under way, not a word of actual testimony was made public until mid-June, after the hearing had concluded.

If McCarthy's eventual downfall may be traced to his crude and offensive behavior during the Senate hearing, his continued influence was never more apparent than in the AEC's handling of the Oppenheimer case. Yet Oppenheimer was not merely a casualty of McCarthyism. He was, to a considerable degree, also the victim of his own stubborn pride. He insisted that the hearing go forward because he feared that if he acquiesced in the loss of his consultant's contract he would be conceding that he was "unworthy." He wanted to believe that the many contributions he had made to making the United States a nuclear power would outweigh his earlier radical associations; that his lofty standing in the scientific community would protect him from retaliation by a government anxious not to alienate members of that community; and that his personal friendship with many trusted leaders of the foreign policy, business, and educational establishments would compensate for the doubts he had expressed about developing the hydrogen bomb.

2.

The origins of the Oppenheimer hearing are usually traced to the letter that William L. Borden (formerly the chief of staff of the Joint Committee on Atomic Energy) wrote to FBI director J. Edgar Hoover on November 7, 1953, in

2. Cited in Robert Griffith, The Politics of Fear: Joseph R. McCarthy and the Senate (New York, 1970), 249. 
which he asserted that the physicist was "more probably than not . . . an agent of the Soviet Union." 3 Hoover forwarded the letter to the AEC and to the White House, and on December 3 President Eisenhower secretly erected a "blank wall" between Oppenheimer and national security information. It was not until December 21, however, a week after Oppenheimer's return from a trip to Europe, that AEC chairman Lewis L. Strauss and general manager Kenneth D. Nichols met with him to explain that his clearance had been suspended. They also handed him a draft of the charges on which the suspension was based. Shaken and distraught, Oppenheimer, who had been given no inkling of what was in store for him, was informed that he could either contest the suspension or quietly terminate his consultant's contract and thereby avoid a hearing. Given only a day to decide, Oppenheimer, on the morning of December 23, informed Strauss that he wanted the opportunity to clear his name.

At this stage the Eisenhower administration was motivated less by a belief that Oppenheimer's continued clearance imperiled national security than by a fear that failure to act would expose it to attack from Senator McCarthy. As early as May 19, 1953, McCarthy and his aide Roy Cohn had visited FBI director J. Edgar Hoover to ask how he would react to an investigation of Oppenheimer. Hoover tried to dissuade McCarthy from proceeding, not because he wished to protect Oppenheimer, whom he distrusted, but because he thought the senator could bungle the investigation and antagonize scientists throughout the nation. In June, it was Lewis L. Strauss's turn to warn the Senate's Republican leadership that an investigation by McCarthy of Oppenheimer would be "a most ill-advised and impolitic move."4 But by December, with Borden's letter circulating within the executive branch and likely to fall into McCarthy's hands, the Eisenhower administration thought it had to do something. The strategy succeeded: in April 1954, when McCarthy finally got around to denouncing Oppenheimer for having delayed work on the hydrogen bomb, he said he had decided against an investigation because of assurances "from top Administration officials that this matter would be gone into in detail." 5

At the time, those who sympathized with Oppenheimer regarded a hearing by the AEC's Personnel Security Board as infinitely preferable to an inquiry by Senator McCarthy. A mudslinger if there ever was one, McCarthy was known for browbeating witnesses, scandal-mongering, and making wild allegations. By contrast, the New York Herald Tribune editorialized, the AEC hearing, which "should be in good hands and under sound procedures," would be "conducted with complete fairness." The board would be able to assess the scientist's life and work in their broad context, the argument went; "If

3. See 305 .

4. Cited in Barton J. Bernstein, "In the Matter of J. Robert Oppenheimer," Historical Studies in the Physical Sciences 12 (1982): 207.

5. The Washington Post, April 14, 1954. 
the case had been taken up by Senator McCarthy, such perspective and judgment would have been impossible." 6

The proceedings before the Personnel Security Board had all the outward trappings of just such an impartial hearing. Oppenheimer was represented by a team of eminent attorneys headed by Lloyd K. Garrison. He was permitted to answer the charges against him in whatever way and at whatever length he wished. His lawyers were allowed to call as many witnesses as they wanted in his behalf, and the board made efforts to accommodate their schedules. His lawyers were allowed to cross-examine all the hostile witnesses to the extent they thought desirable. The discourse in the hearing room was ordinarily quite polite, punctuated only infrequently by harsh comments or bitter rejoinders. Oppenheimer's attorney complimented the members of the board for their courteousness, and they in turn thanked him for his cooperation. Without fail, the board members and the AEC attorney addressed Oppenheimer deferentially, either as "Dr. Oppenheimer" or, more simply, as "Doctor."

Yet if the "odious courtesies," as Kafka would have called them, were fully observed, the hearing in truth lacked fundamental elements of due process, the most egregious example being the surveillance of Oppenheimer by the FBI, which began on January 1, 1954. At the urging of Lewis L. Strauss, FBI agents observed Oppenheimer's home and office, listened in on his telephone conversations, and had him tailed wherever he went. The telephone taps were particularly useful in providing information about his travel plans, thus making it easier for informants to follow him. As the historians of the AEC report, "The only privacy accorded Oppenheimer by the FBI were conversations within his own home."7

What made this surveillance particularly sinister was that it inevitably picked up information concerning Oppenheimer's discussions with his attorneys, information that was passed on to Strauss who then passed it on to Roger Robb, the attorney retained by the AEC to present the case against Oppenheimer. So patently unethical was this aspect of the surveillance that it troubled the FBI agent in Newark who was in charge. He questioned the propriety of the coverage "in view of the fact that it might disclose attorney-client relations." He was told that the "rather full spot surveillances and the technical surveillance" were "of great assistance." Not only was the surveillance justified on the grounds that "there is no criminal action pending against Oppenheimer," but the FBI also wished to guard against the danger that he might defect: "Our chief concern is to know immediately of any indication that Oppenheimer might flee."8

A preposterous fear, indeed, and a telling reflection of the times, it nevertheless helped rationalize continued surveillance. The bugs and wiretaps

6. Editorial, New York Herald-Tribune, April 14, 1954.

7. Richard G. Hewlett and Jack M. Holl, Atoms for Peace and War, 1953-1961: Eisenhower and the Atomic Energy Commission (Berkeley, 1989), 80.

8. Cited ibid., 81. 
were kept in place, and it is also possible that the FBI "had successfully secured an informant among Oppenheimer's inner circle of friends and associates." ${ }^{9}$ Consequently, Strauss received reports, almost daily, regarding Oppenheimer's efforts to obtain legal counsel, to develop a defense strategy, and to line up witnesses in his behalf. The FBI even forwarded information about the meetings of partners in the law firm Oppenheimer retained-Paul, Weiss, Rifkind, Wharton \& Garrison-at which they discussed the conditions under which they would handle the case, and the degree to which various members of the firm would participate in it.

Any acquaintance of Oppenheimer's, no matter how prominent or respectable, could be caught in the spidery web of surveillance. Here, for example, is what the FBI discovered as it followed Oppenheimer during one twenty-four-hour period. On the afternoon of January 10, 1954, Oppenheimer flew from New York City to Boston to attend a meeting of the Harvard College Board of Overseers, which was scheduled for the following morning, and he returned to New York City later that afternoon. The FBI obtained reports on his doings from four confidential sources "of known reliability." These informants observed Oppenheimer as he arrived at the airport terminal in Boston at 6:15 P.M., overheard the arrangements he made to share a taxicab, followed him to a 7:00 P.M. dinner party in Cambridge, waited outside until midnight when he left, trailed him as he was driven to the Harvard faculty club, noted that he attended the Board of Overseers meeting at 11 A.M. the next morning, reported that his return flight was canceled because of a snowstorm but that Oppenheimer boarded a 3 P.M. train to New York City after telephoning his wife to let her know that he would arrive at Pennsylvania Station at 7:20 P.M. The FBI report noted that the dinner party was hosted by U.S. District Court judge Charles E. Wyzanski, that one of the guests, Robert Fiske Bradford, was a former Republican governor of Massachusetts, and that another guest, McGeorge Bundy, was dean of the faculty of arts and sciences at Harvard. ${ }^{10}$

On April 7, as the date of the hearing approached, the FBI agent in Newark again inquired as to whether the surveillance at Princeton ought to be terminated. He noted that the telephone tap had periodically furnished Strauss with information "mainly bearing on the relationship between Oppenheimer, his attorneys, and potential witnesses for Oppenheimer at the forthcoming AEC hearing. Absolutely no information of security interest has been obtained from the technical." All the charges against Oppenheimer, the agent continued, related to his activities in the period before 1943 and to his alleged opposition to the hydrogen bomb. "We have no substantial information of a procommunist nature concerning Oppenheimer subsequent to 1943." Since Oppenheimer would be in Washington once the hearing began, "there appears

9. Ibid., 85.

10. Special Agent, Boston, Report, January 13, 1954, FBI File. 
to be no logical reason for continuing the technical surveillance." But a note at the bottom of the agent's wire reads: "Strauss requested tech be continued for about 2 weeks till after hearing." 11 And on April 13, a day after the hearing began, Strauss agreed that while physical surveillance of Oppenheimer in Washington was unnecessary, the telephone tap in Princeton ought to be continued "as it has been most helpful."12

Although Oppenheimer had reason to suspect his telephone was tapped, he did not know how extensive the surveillance was or how fatally it undermined the principle of attorney-client confidentiality. $\mathrm{He}$ and his lawyers were all too aware, however, of another objectionable aspect of the proceedings. For a week before the hearing began, the members of the Personnel Security Board-Gordon Gray, Thomas A. Morgan, and Ward V. Evans-immersed themselves in the secret files that the FBI and other agencies had compiled on Oppenheimer over the years. Worse still, the board members examined the files in the presence of Roger Robb, the AEC attorney who would soon present the case against Oppenheimer. Far from facing a panel that had no preformed opinion, Oppenheimer would appear before men whose minds, to some extent, had already been made up by the reading of dossiers that contained (as secret dossiers always do) derogatory information, much of it unsubstantiated. Meanwhile, Robb had an opportunity to put a negative spin on the files, an opportunity, it must be assumed, he did not let pass. At the very least, as a result of a week's socializing with the board members, Robb "became their close associate, not an attorney presenting material before an impartial panel."13

Oppenheimer's attorney, Lloyd K. Garrison, could not contain the damage because the AEC rejected his requests either to see the secret files or to meet with the board in advance to respond, even in general terms, to concerns raised by information contained in them. Garrison remembered having "a kind of sinking feeling" when he realized that the board had "a week's immersion in FBI files which we would never have the privilege of seeing, and of coming to the hearings with that intense background of study of the derogatory information." As a result of the board's "preliminary immersion in the secret files," Garrison realized, "a cloud of suspicion hung over Robert Oppenheimer."14

That cloud would not have been dispelled even if Garrison had succeeded in obtaining security clearance since he still would not have been granted access to secret FBI files. But, in fact, he never obtained clearance and his failure to do so placed Oppenheimer at a serious disadvantage. On January 18, 1954, the AEC informed Garrison that it was willing to expedite his application for a "Q" clearance, but he insisted that two of his colleagues, Herbert Marks and

11. W. A. Branigan to A. H. Belmont, April 7, 1954, ibid.

12. J. E. Hoover to the Attorney General, April 13, 1954, ibid.

13. Bernstein, "In the Matter," 218.

14. Philip M. Stern, The Oppenheimer Case: Security on Trial (New York, 1969), 527-28. 
Samuel Silverman, also be cleared. When the AEC balked, Garrison decided to withdraw his own request, explaining, "We felt that unless all three of us were given clearance, none of us should be. ... [W] would be working constantly together, and it would be impractical for one of us to be privy to documents and testimony whose nature he would have to conceal from the others." Not until March 26, two weeks before the hearing opened, did Garrison reconsider and request clearance as "a precautionary measure to ensure that at all times there would at least be one person who could be at Robert's side." ${ }^{15}$ By then it was too late. At four different times during the course of the hearing Oppenheimer's attorneys were asked to leave the room, and at no time were they permitted to see any material in Oppenheimer's dossier that remained classified.

3.

The surveillance, suspicion, and secrecy all rendered Oppenheimer particularly vulnerable, and Roger Robb was quick to exploit his advantage. As Robb understood, he did not have to prove beyond a reasonable doubt that Oppenheimer was a security risk; rather, Oppenheimer had to persuade the board that he was not one. To do this, Oppenheimer thought, required that he be cooperative, even to the extent of answering questions about the political affiliations of friends and former students. In effect, he played the role of an informer, however distasteful he found it. At one point, after listing a number of names, Oppenheimer was asked, "would you break them down? Would you tell us who the Communists were and who the fellow travelers were?" Oppenheimer finally exclaimed, "Is the list long enough?"16 His embarrassment at having named the names of men and women who trusted him was made all the more acute in mid-June when the AEC suddenly decided to publish the transcript of the hearings, which, it had been assumed, would remain secret.

There was, however, one person about whom Oppenheimer refused to express doubts: his younger brother, Frank. One of the more insidious aspects of Robb's questioning was his attempt to use Robert's loyalty to Frank to undermine his credibility. By 1954, Frank Oppenheimer's past membership in the Communist Party was a matter of record, and he had paid a high price for it. Frank joined the Party (along with his wife, Jacquenette) in 1937 when he was a graduate student in physics at the California Institute of Technology; he left the Party in 1941, shortly before being employed at the Radiation Laboratory at Berkeley. After the war he joined the physics department at the University of Minnesota. In 1947, when a newspaper report asserted he had been a Communist, he issued a denial. But in 1949, subpoenaed to testify under oath before the House Committee on Un-American Activities, Frank admitted his 
past membership; he agreed to talk about his own involvement although not to implicate anyone else. He submitted his resignation to the University, not anticipating it would be accepted, but in fact it quickly was. Frank moved to Colorado, where he became a sheep rancher, and that is what he was doing at the time of his older brother's security hearing.

Even after all these years, it remains excruciatingly painful to observe Robb's effort to turn brother against brother. Having gotten Robert to admit that even in the 1940s he believed that membership in the Communist Party "was inconsistent with work on a secret war project," Robb then asked whether the same was true for former members of the Party, such as Frank. When Oppenheimer replied that it all depended "on the character and the totality of the disengagement and what kind of a man he is, whether he is an honest man," Robb asked what test he applied in the 1940s to "satisfy yourself that a former member of the party is no longer dangerous?" "In the case of a brother, you don't make tests," he answered. His brother, Oppenheimer said, had told him he left the Party in 1941. "You were satisfied at that time that your brother was not a member of the party any more?" "Yes." "How did you reach that conclusion?" "He told me." "That was enough for you?" "Sure." Had Oppenheimer informed security officers at Berkeley about Frank's past membership? "Did you tell [them] he had been a member of the Communist Party?" "I don't think so." Finally, having gotten Oppenheimer to agree that the fact that a person says he is no longer a Party member "does not show that he is no longer dangerous as a security risk," Robb asked, "Do you think your brother today would be a good security risk?" "I rather think so." ${ }^{17}$

Oppenheimer's desire to protect his brother may well explain his unwillingness, during and after the war, to tell the whole truth about the "Chevalier incident," which played a central role at the hearing. In February or March 1943, just before leaving California for Los Alamos, Oppenheimer had a conversation with Haakon Chevalier, a left-wing friend and a professor of French at Berkeley. Chevalier reported that a mutual acquaintance, George Eltenton, a British engineer, had said there might be a way to get information about atomic research at the Radiation Laboratory to the Russians. That would be terribly wrong, Oppenheimer said, and the matter was quickly dropped, but he neglected to report it to security officers at Los Alamos, and when he finally did he invented a partly fictitious story. Indeed, at first he refused even to provide Chevalier's name. The FBI believed it had credible evidence-and so informed the AEC-that Oppenheimer failed to divulge all the details because to do so would have implicated his brother, Frank.

Whether Chevalier had approached each brother separately, or had spoken to Frank who then spoke to Robert, remains unclear. What is certain is that Robert had informed General Leslie R. Groves, the head of the Manhattan Project, that Frank was involved, but only after extracting a promise from Groves not to tell anyone. According to the historians of the Atomic En- 
ergy Commission, “Oppenheimer secured Groves's pledge not to report his brother's name to the FBI, thereby incredibly implicating the head of the Manhattan Project in his story."18 A man of his word, Groves did not mention Frank's name in any report he made during the war. At the 1954 hearing, however, Groves said of Oppenheimer: "It was always my impression that he wanted to protect his brother, and that his brother might be involved in having been in this chain, and that his brother didn't behave quite as he should have, or if he did, he didn't even want to have the finger of suspicion pointed at his brother, because he always felt a natural loyalty to him, and had a protective attitude toward him." 19 There were no follow-up questions from Robb about Groves's covering up of Oppenheimer's “cock-and-bull” story during the war.

But Robb pursued Oppenheimer relentlessly for having concocted the story. Relying on the transcripts of Oppenheimer's conversations with an army counterintelligence officer, Lt. Col. Boris T. Pash, Robb made it appear that Oppenheimer was a habitual, inveterate liar. Robb's first question: "Did you tell Pash the truth about this thing?" "No," Oppenheimer said. Robb's second question: "You lied to him?" "Yes," Oppenheimer replied. Robb's third question: "What did you tell Pash that was not true?" Oppenheimer answered truthfully: "That Eltenton had attempted to approach members of the project-three members of the project-through intermediaries." Robb's fourth question: "What else did you tell him that wasn't true?" When Oppenheimer said, "That is all I really remember," Robb, referring to the transcript, asked a fifth question: "That is all? Did you tell Pash ... ," and then implied that Oppenheimer's failure to remember everything he had said in a decade-old interview amounted to purposeful deception. When Oppenheimer again admitted making up the story, Robb asked, "Why did you do that, Doctor?" One would have thought Oppenheimer's reply-“Because I was an idiot"-would have sufficed. But Robb was not done: "Is that your only explanation, Doctor?"20

Not only did Robb pillory Oppenheimer for having lied about the Chevalier incident; he also exploited the "fabrication and tissue of lies"-an inaccurate description, perhaps, but one that Robb at one point induced Oppenheimer to accept-to shake the credibility of witnesses testifying in Oppenheimer's behalf. When, for example, friendly witnesses maintained that Oppenheimer's lack of truthfulness in the Chevalier incident was insignificant in view of his overall record and, in any case, had no sinister connotations, Robb asked whether they would have reported a suspicious overture under similar circumstances, a question that naturally allowed only one answer. When James B. Conant (who was formerly president of Harvard University and was then serving as United States High Commissioner to Germany) appeared, it was board member Ward V. Evans who asked: "Wouldn't you have reported it just

18. Hewlett and Holl, Atoms for Peace and War, 96.

19. See 78 .

20. See 67-68. 
as quickly as you could?" "I think I would have, yes. I hope I would have; let us put it that way." At this point, Robb injected: "When you did report it, Doctor, you would have told the whole truth about it?" "I hope so." "I am sure you would."21

Robb also raised another subject designed to humilitate Oppenheimer-his overnight visit to his former fiancée, Jean Tatlock, in Berkeley, in June 1943. Although Oppenheimer had admitted seeing her, his statement had not mentioned staying at her apartment. Now he said that Tatlock had wanted to see him "because she was still in love with me." Robb's questions were pitiless: "You have no reason to believe she wasn't a communist, do you? ... You spent the night with her, didn't you? . . . That is when you were working on a secret war project? ... Did you think that consistent with good security? ... You didn't think that spending a night with a dedicated Communist . .?" Robb's questions were presumably designed to show that Oppenheimer was careless about security; but by reiterating the suggestive phrase "spending the night," he was characterizing Oppenheimer as an adulterer. ${ }^{22}$

Yet Robb wanted more from Oppenheimer than an admission that he had once lied to security officials or had behaved indiscreetly. One of the AEC's chief allegations was that Oppenheimer had opposed a crash program to develop the hydrogen bomb in 1949, and had slowed progress toward the weapon by letting other physicists know his position. Robb therefore wanted Oppenheimer to confess that, having worked on the atomic bomb, his opposition to the hydrogen bomb could not have been based on moral scruples. The implication was clear: if Oppenheimer's reservations about the hydrogen bomb were not ethically derived, they must have been motivated by proRussian sentiment.

Partly to avoid the trap Robb was setting, Oppenheimer, when asked whether he had "moral scruples" about the use of the atomic bombs against Japanese cities, replied, "terrible ones," although as Robb well knew, and Oppenheimer had earlier admitted, he had voiced no such doubts before the bombing of Hiroshima and Nagasaki. This colloquy then followed: "But you supported the dropping of the atom bomb on Japan, didn't you?" "What do you mean support?" "You helped pick the target, didn't you?" "I did my job which was the job I was supposed to do. I was not in a policymaking position at Los Alamos. I would have done anything that I was asked to do, including making the bombs in a different shape, if I had thought it was technically feasible."23

4.

In view of the many disadvantages Oppenheimer faced during Robb's hostile cross-examination, and the admissions he made, the outcome was never

21. See 152-53.

22. See 74.

23. See 97. 
in doubt. Just a week into the proceeding, well before most of Oppenheimer's witnesses had even appeared, Lewis L. Strauss told an FBI agent "that he was most happy with the way the Oppenheimer hearing was going and said he had been in conference each day with Rolander and Robb who are handling the matter before the board and was convinced that in view of the testimony to date the board could take no other action but to recommend the revoking of Oppenheimer's clearance." 24 The hearing concluded on May 6 and three weeks later, on May 27, the board issued just such a report. Filled with sanctimonious self-praise- - "the Board has allowed sympathetic consideration for the individual to go hand in hand with an understanding of the necessities for a clear, realistic, and rugged attitude toward subversion, possible subversion, or indeed broader implications of security"-the majority report, signed by Gordon Gray and Thomas A. Morgan, concluded that Oppenheimer was "a loyal citizen" but that his "continuing conduct and associations" reflected a disregard for security requirements, and that his views regarding the hydrogen bomb program were "sufficiently disturbing as to raise a doubt as to whether his future participation ... would be clearly consistent with the best interests of security." 25

Now Oppenheimer and his attorneys faced a truly Kafka-esque situation. The board's report went to the AEC's general manager, Kenneth D. Nichols, for his use in formulating a recommendation to the full commission, which would make the final determination. By this point, however, none of Oppenheimer's judges were saying what they really believed. Gray and Morgan did not believe Oppenheimer was a loyal citizen, but only that the evidence did not prove conclusively that he was not loyal. Ward V. Evans submitted a minority report that he did not write: his draft was so embarrassingly inadequate that Roger Robb-of all people!-rewrote it, which may explain why it was long on rhetoric and short on facts. Oppenheimer's lawyers labored over a response defending him against the board's charge that he had delayed production of the hydrogen bomb, even as Nichols was drafting a letter of "transmittal" to the AEC-again, with the assistance of Roger Robb-that reformulated the charges, eliminating any criticism of Oppenheimer for the advice he had given on the hydrogen bomb. Neither Nichols nor Robb, however, really thought that Oppenheimer was blameless on this count; they merely feared alienating the scientific community if he were to be condemned for having given his honestly considered opinion on a technical matter.

If ever a person charged with impartially weighing evidence and making an evenhanded ruling ought to have recused himself, it was AEC chairman Lewis L. Strauss. From the outset, he had masterminded the crusade against Oppenheimer. He had been instrumental in arranging for the intrusive FBI surveillance. He had offered Robb advice on how to cross-examine witnesses. He had put pressure on witnesses reluctant to appear if he thought their testimony

24. A. H. Belmont to L. V. Boardman, April 17, 1954, FBI File.

25. See 355,360 . 
would work to Oppenheimer's disadvantage. He had resolved to vote against restoring Oppenheimer's security clearance long before he read the transcript of the hearing, the Personnel Security Board's report, Garrison's brief filed in Oppenheimer's behalf, or Kenneth D. Nichols's letter of transmittal. According to the historian Barton Bernstein, Strauss's opinion, which was joined by commissioners Eugene Zuckert and Joseph Campbell, "was simply a way of expressing Strauss's suspicion and hostility without moving so far beyond the evidence to invite full-scale attacks on Strauss himself, the AEC, the loyaltysecurity system, and the Eisenhower administration."26

Roger Robb, who had a hand in drafting the Personnel Security Board's majority and minority reports, and Nichols's letter of transmittal, also helped Strauss write the AEC's final opinion. Returning to the theme of Oppenheimer's "fundamental defects in character," Strauss and Robb cited several examples that they thought had been adequately documented in the hearing, but then went on to suggest, without offering any proof, that the work of military intelligence, the FBI, and the AEC "all at one time or another have felt the effect of his falsehoods, evasions, and misrepresentations." ${ }^{27}$ At the end as in the beginning there was the implication that secret information, stored in sensitive files, available only to those with the highest-level security clearance, supported a conclusion that, to those not having access to the information, may well have seemed unreasonable.

On learning of the AEC's four-to-one vote against Oppenheimer, President Eisenhower, his press secretary noted, "personally called Strauss to congratulate him on the fine job he had done in handling a most difficult situation. The president expressed hope that handling of the Oppenheimer case would be such a contrast to McCarthy's tactics that the American people would immediately see the difference." ${ }^{28}$ Notwithstanding the president's belief that the procedures followed in the Oppenheimer hearing contrasted sharply with McCarthy's inquisitorial tactics, those procedures were marred by personal bias, political partisanship, and procedural irregularities. Lewis L. Strauss, Kenneth D. Nichols, Roger Robb, and J. Edgar Hoover had an instinct for the jugular no less sure than Joe McCarthy's.

They also had an instinct for public relations that would have done McCarthy proud. Given Oppenheimer's eminence, Borden's letter, the president's "blank wall," and the rather complicated logistics of the Personnel Security Board hearing, it was only a matter of time before the story broke. From the outset, therefore, both sides realized it would be advantageous to place its version before the public in the most favorable light possible. In this contest, however, Oppenheimer was overmatched, hampered by a fear of

26. Bernstein, "In the Matter," 242-43.

27. See 383.

28. James Hagerty Diary, June 29, 1954, cited in Bernstein, "In the Matter," 241. 
alienating those who sat in judgment on him, while Strauss, of course, had no such concerns.

In January 1954, New York Times reporter James Reston found himself, by chance, in a seat next to Oppenheimer on a flight from Washington to New York City. Reston described him as "thin and slightly stooped, with short gray hair and startling blue eyes," but more importantly, sensed that Oppenheimer seemed "unaccountably nervous in my presence and obviously under some strain." So Reston, on his return to the Capital, began "snooping around and asking 'What's wrong with Oppenheimer these days?" "29 The trail soon led to Lloyd K. Garrison who eventually turned over the AEC's letter suspending the physicist's clearance but got Reston to agree not to publish anything, at least until Oppenheimer had prepared his reply. At about the same time, Joseph and Stewart Alsop of the New York Herald Tribune, ardent admirers of Oppenheimer, also discovered what had been going on. Strauss knew about Reston's contact with Garrison (from an FBI report) and of the Times's arrangement to withhold publication (from its publisher).

On April 9, three days before the hearing was to begin, both sides became alarmed at the prospect that Joe McCarthy - who made a statement darkly alluding to an eighteen-month delay in producing the hydrogen bomb-was going to break the news of the charges against Oppenheimer and the suspension of his clearance. Both Oppenheimer and Strauss, for different reasons, preferred that the first public account be a responsible one, that is, Reston's in the Times, although neither wanted the onus of having breeched the agreedupon confidentiality. At a White House meeting on April 9, Eisenhower's press secretary James Hagerty and Strauss devised a strategy they hoped would induce the Times to publish the story. Strauss had pledged to let the newspaper know if the story was going to break elsewhere; he now retracted that pledge; that led the Times to tell Garrison the story was about to break, and he, in turn, authorized the Times to release the text of the documents and Reston's article. When the story appeared on the morning of April 13, Gordon Gray, knowing nothing of the intrigue, sharply rebuked Garrison and Oppenheimer for going public.

This was only the first of several attempts to use the press for the purposes of influencing public opinion. On June 1, Oppenheimer's camp released the text of the Personnel Security Board report and Lloyd K. Garrison's rebuttal, thereby infuriating Eisenhower, who remarked: "This fellow Oppenheimer is sure acting like a Communist. He is using all the rules that they use to try to get public sentiment in their corner on some case where they want to make an individual a martyr." ${ }_{0}$ Then, on June 15, the AEC decided to release the full transcript of the hearings. That decision, which violated assurances of confidentiality given to all the witnesses, was made after Strauss received two FBI 


\section{XXviii INTRODUCTION}

surveillance reports, one claiming that Oppenheimer was considering releasing only those parts of the transcript favorable to himself, the other that Oppenheimer's attorneys had been overheard saying that publication of the entire transcript "would have a devastating effect on Oppenheimer's image." 31 The accidental, if temporary, loss of a classified document by one of the AEC commissioners permitted Strauss to obtain approval for publication.

Publication of the transcript did not have a devastating effect on Oppenheimer but it certainly embarrassed him. There, for all to see, were his confessions of wrongdoing, his willingness to inform on his former students and colleagues, his discomfort when asked about the night with Jean Tatlock, and, above all, his seemingly inexplicable timidity in the face of Robb's bulldog-like cross-examination. To make doubly certain that releasing the transcript would have the desired effect, the AEC provided the press with a memorandum drawing attention to the passages in the 992-page document in which Oppenheimer admitted that the original story he told security officers about the Chevalier incident in 1943 was "a tissue of lies."

"Had we anticipated the way in which the Commission was to present the transcript to the public," Lloyd K. Garrison recalled, "we might have published it first ourselves, through Mr. Reston." Garrison explained that Oppenheimer had decided against releasing the document partly because of the assurances of secrecy given to witnesses, and partly because the case was still pending before the AEC. There was still a chance, however remote, that the commission would find in his favor, Garrison explained, but "if we were to publish the transcript in advance of the decision, we might disturb the Commission and perhaps prejudice the outcome."32

The immediate response to the publication of the transcript focused on the merits of the AEC's decision. A few who had sympathized with Oppenheimer were now persuaded that the evidence justified the action, while others, like Joseph and Stewart Alsop, thought the testimony demonstrated a miscarriage of justice as notorious as that in the infamous Dreyfus case. ${ }^{33}$ Unfortunately, not nearly as much attention was paid at the time to the broader significance of the transcript, which provided an invaluable source of information about the history of nuclear development during the war, the debate among scientists over the hydrogen bomb, the conflict between the foreign policy and military establishments over national defense, the controversy over the proper standards to apply in assessing an individual's loyalty, and the ethical and moral dilemmas involved in combating the perceived menace of communism. Like a latter-day Greek tragedy, the transcript also offered insight into such timeless traits of human character as honor, fortitude, and humility, and, sadly enough, their less admirable counterparts: treachery, timidity, and pride.

31. Ibid., 241.

32. Stern, Oppenheimer Case, 522.

33. Joseph and Stewart Alsop, We Accuse! The Story of the Miscarriage of American Justice in the Case of J. Robert Oppenheimer (New York, 1954). 